\title{
"Effect of Recruitment Strategies of Employees on Service Delivery in Local Authorities in Kenya: A Case of Nyamira County, Kenya"
}

\author{
${ }^{1}$ Rebecca Onchari, ${ }^{2}$ Dr. Mike Iravo, ${ }^{3}$ Dr. Charles Munene Elijah
}

\begin{abstract}
Efficiency in recruitment and selection has a positive bearing on service delivery. This study established the effect of recruitment strategies of employees on service delivery in local authorities in Nyamira County, Kenya. The objectives of the study were to identify the major recruitment strategies used by the municipal council of Nyamira in employment of employees, to establish the effect of the recruitment strategies of the employees on service delivery to the public in Nyamira Municipality and to determine the challenges facing the Nyamira Municipality in recruitment process of the employees. This study adopted a case study research design as it had the potential to generate rich subjective data that could lead to the development of a theory. It provides baseline information on the structure of the municipality of Nyamira and examines its middle level staff in their effective delivery of services to the residents of Nyamira town. The target population comprised of 200 employees from within the municipal council. For getting a representative sample, the researcher stratified the employees into three groups basing on the salary grade and the area of working. All the five members of the management and all the ten supervisors were included in this study purposively. Simple random sampling was used to select 85 employees in scale 13-20. This method was appropriate to give employees equal and independent chance of being selected. The researcher collected data directly from the respondents by use of research instruments basically questionnaires and oral interviews. Data was then be analyzed, interpreted and presented by use descriptive statistical techniques. This study revealed the reasons for poor delivery of services as laying on recruitment strategies employed. It therefore recommended to the ministry of local government to establish causes of poor service delivery by the local authorities in relation to recruitment strategies. Corrective measures may be taken with regard to the local authority Act.
\end{abstract}

Key words: Recruitment strategies, Local Authority

\section{Introduction}

Recruitment is the process of identifying and attracting a group of potential candidates from within and outside the organization for employment. External candidates have an advantage because sometimes they bring skills that may not be available in the organizations' workforce (Tyson, 2000). Normally recruitment precedes selection. It paves way for selection procedure by producing a small number of candidates who appear to be able to perform the required tasks of a job from the onset. The purpose of recruitment is to help the employing organization not to waste a lot of time and money on people whose qualifications do not match the requirements of the job shown, (Armstrong, 2006). It helps to get the applicants who are likely suitable to fill the job vacancy.

According to Dessler (2008), recruitment does not just involve placing or calling the employment agencies for candidates but the following elements should be considered; Recruitment process should take account of the company's strategic plan. For instance, if a company has expanded or has opened new branches, recruitment strategy to be adopted should depend on the type of job you are recruiting for; non-recruitment issues such as paying higher than what other firms in your locale pay; the firm's image will affect recruitment results, for example, a poor reputation will make it difficult for the firm to recruit talent. Shaun (2000) observes that vacancies for recruitment in an organization come due to changes in policy, technology, location, mergers, acquisitions, demergers and when employees leave the organization and need to be replaced.

Dessler (2008) argues that the US department of labour accepts the public nonprofit agencies as well as privately owned agencies in the recruitment process. The US department of labour supports these agencies through grants and a nationwide job bank. The job bank enables agency counselors in one state to advise applicants about available jobs, not just in their local area but in other areas as well . Private agencies on the other hand are important sources of clerical, white collar and managerial personnel. They charge fees for each applicant they place yet using employment agencies help in avoiding potential pitfalls for example the agency's screening may let poor applications by pass the preliminary stages of the selection process.

Hagg (2004) asserts that the main objective of the local government system is to provide democratic and accountable government ensuring the provision of services to communities in a sustainable manner, promoting social and economic development, providing a safe and healthy environment and encouraging the 
involvement of communities and community organizations in local government. Consequently, if local authorities are poorly managed, corrupt and ineffective in their operations, then the central government inevitably will have same traits. The effectiveness of government operation largely depends on the human resource therein. Most of Kenya's urban centres have witnessed dramatic growth in population yet there has not been seen remarkable growth in the human capacity of local authorities to effectively respond to the required services to the required services to the public (Republic of Kenya, 1999).

It is the priority of the Kenyan government to strengthen the local governments in its effort to improve overall public sector management. The Economic Recovery Strategy (ERS) annual progress report (2004/05) stresses the need to accelerate the local government reform process in order to improve local service delivery and governance.

Recruitment and staffing is one of the fundamental issues of human resource management. Like in other sectors of government the nature of staff in local authorities affect service delivery to the public. It follows that improved efficiency and recruitment of local authorities are a requisite towards effective service delivery. Efficient employment strategies should be adopted mostly through an independent recruitment body to ensure selection of an efficient staff in respective offices (ERS, 2004/05). This is a staff with competence, experience, knowledge in the area of operation; self motivated and ready to deliver services.

According to the ROK (1999), local authorities have two basic recruitment strategies: the chief officers are recruited by the public service commission while the middle level officers and the junior staffs are recruited within the municipality in question. These are categorized according to salary grades and department of operation. The Nyamira County comprises the Nyamira County council, Nyamira Town council and Nyansiongo Town council of which the local authorities do recruit middle level employees. Given the importance of the LAs, it is important to establish the effect of the recruitment strategies employed on the performance of the employees to improve service delivery in the county.

\section{The Statement of the Problem}

The quality of service provision is less than desirable, as well, with key services such as housing, clean water, sewerage disposal, street lighting, collection and disposal, cemetery services, construction of markets, health, education, environmental hygiene and generally proper planning of the town remaining dismal. Of the more than two hundred employees in the local authorities in Nyamira County, only three are employed by the public service commission through the ministry of local government. The rest are locally employed and the council depends solely on these for delivery of services to the public (ROK, 2012). There is however a public outcry on poor service delivery. The local council seems to collect large revenue from the public yet little is done for the public in terms of what the county council is charged to provide. This study established the effect of recruitment strategies of middle level employees on service delivery to the public in Nyamira County to ensure that delivery of services is effective and efficient.

\section{General Objective of the study}

The general objective of the study was to establish the effect of recruitment strategies of employees on service delivery in local authorities in Kenya. The study covered Nyamira County.

\section{Objectives of the Study}

The study used the following specific objectives:

1. To identify the major recruitment strategies used by the LAs of Nyamira County in employment of employees.

2. To assess the effect of the recruitment strategies of the employees by the LAs on service delivery to the public in Nyamira County.

3. To examine the challenges facing the LAs in Nyamira County in the recruitment process of the employees

\section{The Scope of the Study}

The study was carried out in the LAs of Nyamira County. The LAs in Nyamira County are Nyamira County, Nyamira Town and Nyansiongo Town Councils. The study took place as from January to March 2013. The main respondents for the study were the clerks, Town engineers, Town treasurer and the employees of the County. It focused: to identify the major recruitment strategies used by the LAs of Nyamira County in employment of middle level employees; to establish the effect of the recruitment strategies of the middle level employees by the LAs on service delivery to the public in Nyamira County and to determine the challenges facing the LAs in Nyamira County in the recruitment process of the middle level employees. 


\section{Significance of the Study}

The rationale of the study is to contribute knowledge and lay foundation for further research on recruitment strategies. It will also shed light on the recruitment of employees in the LAs as they seem to be performing below expectations in provision of services to the public.

This study may reveal to the ministry of local government on the causes of poor service delivery by the local authorities in relation to recruitment strategies. Corrective measures may be taken with regard to the local authority Act.

The study will unearth challenges facing the local authorities in the recruitment process and allow corrective measures to be taken based on the local authority's Act. The study will provide baseline information to senior officers in the LAs of Nyamira County on how to improve service delivery and enhance local government effective capacity building in order to promote effective service delivery to the public.

\section{Conceptual Framework}

The study employed a conceptual framework in which the independent variables (I.Vs) were: recruitment strategies, effects of recruitment strategies and the challenges faced by LAs in recruitment of middle level employees. In this case, service delivery of the LAs became the dependent variable (D.V). Recruitment strategies help to get the applicants who are likely suitable to fill the job vacancy and they examine the credentials of candidates so as to produce a short list for the selection procedure efficient recruitment of staff may be described as knowing what resources are available, where and how they may be found. Effects of the recruitment strategies are important as they will determine the services delivered in the local authorities. The challenges faced by the LAs will influence policy reforms on recruitment of middle- level employees in the LAs.

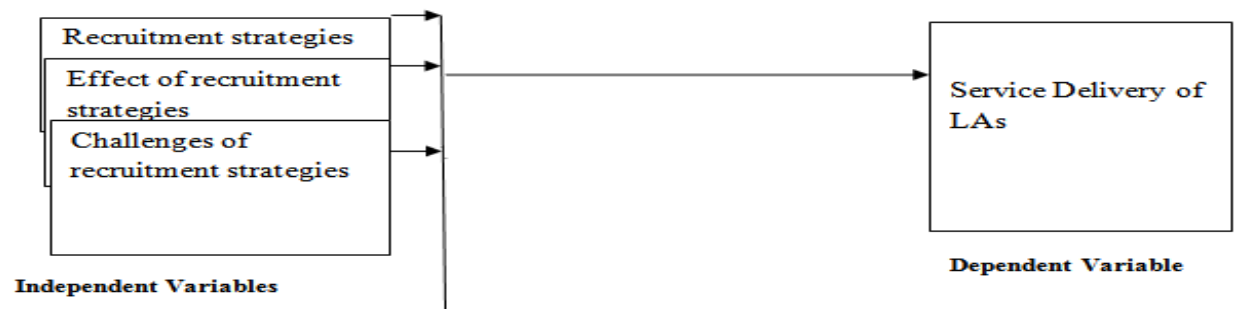

Figure 1: Conceptual Framework

\section{Research Design}

\section{Research Methodology}

This study adopted a case study research design. The case study is a way of organizing education or social data and looking at the object to be studied as a whole(Orodho,2005).The main reason for using the case study is that it has the potential to generate rich subjective data that can lead to the development of a theory. It provides baseline information on the structure of the Local Authorities of Nyamira County and examines its middle level staff in their effective delivery of services to the residents of Nyamira County.

\section{Population sample}

The target group was the two hundred and nine employees in the Local Authorities of Nyamira County who comprise of 3 town clerks, 3 town engineers, 3 town treasurers and 200 employees of the county.

\section{Sample Size and Sampling Procedures}

Sampling is a process of selecting a number of individuals from a population such that the selected group contains elements representative of the characteristics found in the entire group (Orodho, 2005). The study employed purposive sampling in selecting the key informants in the LAs like the town clerks, town engineers and the town treasurers. According to Mugenda and Mugenda (2003), 30\% of the employees' population comprised the sample size. Therefore, the sample size for the study comprised of 3 town clerks, 3 town engineers, 3 town treasurers and 60 employees. Simple random sampling was used to select the employees from the population. The table 1 below shows the sampling frame for the study. 
Table 1: Population sample and sample size

\begin{tabular}{lcc}
\hline Respondents & Population sample & Sample size \\
& & \\
Town Clerk & 03 & 03 \\
Town Engineer & 03 & 03 \\
Town Treasurer & 03 & 03 \\
Employees & 200 & 60 \\
Total & $\mathbf{2 0 9}$ & $\mathbf{6 9}$ \\
\hline
\end{tabular}

\section{Research Instruments}

The main research instrument for this study was a questionnaire. Data collected by use of questionnaires which consisted of closed and open ended questionnaires that consistent with the research objectives and questions. An interview schedule was also used by the researcher to overcome the limitations of the questionnaire. The questionnaire enabled the researcher to cover a wide area and minimize biases.

\section{Piloting of the research instruments}

As Orodho (2005) points out, piloting refers to the pre-testing of research instruments to a selected sample which is identical to the actual sample to be used in the study. He adds that piloting helps to detect deficiencies in the research instruments such as insufficient space and ambiguous questions, and helps to reveal if anticipated analytical techniques are appropriate. A pilot study was conducted in Kisii County council to validate the research instruments and test the reliability of the instruments.

\section{Reliability and Validity of the Instruments}

The reliability and validity of the research instruments were tested before being used in data collection. This process is called standardization of research instruments. Test and retest was used to determine the reliability of the questionnaires. The correlation coefficient between the two separate administrations of the questionnaire gave a coefficient of 0.875 which was high enough to confirm the reliability of the questionnaires. Test and retest was also used to ascertain the validity of the data collected.

\section{Data Collection Procedures}

This refers to the gathering of information to serve or prove some facts (Kombo and Tromp, 2006). It involves the real process of going to the field to get the required information from the selected population. The researcher will seek permission from the College in writing to enable her to get permission from the Management of Nyamira County. After acquiring the permit the researcher will visit the respondents and administer the research instruments to them.

\section{Data Analysis and Presentation}

Data analysis deals with the process of data coding, data entry and analysis in order to make interpretation possible. It is also concerned with the statistics to be used to analyze data, that is, the organization, interpretation and presentation of collected data (Oson and Onen, 2005). Data in this study was collected by use of both closed-ended and open-ended questionnaire items. Quantitative data was analyzed by use of percentages in consideration of the research questions and presented by use of frequency tables, bar graphs and pie- charts. The qualitative data from interview schedules and structured questionnaires were read and categorized into distinct themes as shown by the responses of the respondents. These contributions were then analyzed and interpreted by use of percentages and then presented by use of frequency tables.

\section{Results and Conclusions}

The study sought to find out the effect of recruitment strategies on service delivery in LAs in Nyamira County. The findings revealed that the LAs have not embraced many strategies of recruitment. Modern recruitment strategies like internet have not been embraced. Use of employment agencies, referral schemes and use of employment consultancies have been minimally used as was revealed by the respondents. The major recruitment strategies that were commonly used were interviews and advertisements. There is need to adopt other modern recruitment strategies to attract qualified, skilled and knowledgeable employees to improve service delivery in the county.

Another objective was to assess the effect of the recruitment strategies of the employees by the LAs on service delivery to the public in Nyamira County. The study established that improvement had mainly been achieved in garbage collection and construction of roads. Sewerage disposal and provision of housing was below average while little had been done in other areas of service delivery like fighting fire outbreaks, cemetery services, and provision of clean water, street lighting education and health service. The LAs are entitled to provide all these services to the public in their area of jurisdiction but the findings revealed that the services were inadequate. Education and health services were rapidly shifting from the LAs to the respective ministries. From these 
findings, it can be concluded that most of the employees recruited by the LAs lack the necessary skills and knowledge that can be used to revitalize the services in the respective departments. This could be as a result of the recruitment strategies employed. There is need to enhance the recruitment strategies to improve the delivery of services in the county.

Finally, the study sought to examine the challenges facing the LAs in Nyamira County in the recruitment process of the employees. It was established that the LAs in Nyamira County were faced with various challenges. The greatest challenge was lack of ICT skills and lack of sufficient internet network within the LAs. Other challenges were; poor methods of advertisements, unreliable employment agencies to provide skilled employees. Employment consultancies demand so much in the recruitment process than what the LAs can afford. There was also a challenge of inadequate funds to enable the LAs perform their duties effectively. The findings however revealed that labour turnover was not a big challenge comparatively in the LAs of the county. These challenges may be contributing to poor service delivery and therefore there is need to address the issue of recruitment to curb these challenges.

\section{Recommendations}

With regard to the findings of the study, the following recommendations were made: There is need for the LAs to adopt effective and efficient modern recruitment strategies like internet and use of employment agencies in order to get candidates with skills, knowledge and expertise in various areas of operation so as to improve on service delivery. To address the effect of the recruitment strategies, the LAs should avail and make use of the modern facilities and equipment. With the implementation of devolved governments there is need to increase sources of revenue to the county governments so as to enable them offer the public what is in their mandate. There is need for the central government to offer financial assistance to the LAs to enable them carry out their operations effectively. The challenges facing the recruitment strategies by the LAs can be addressed by the now implemented county government to ensure that right skills and expertise are embraced.

\section{References}

[1]. Adam G \& Schvanavellett (1995). Understudy Research methods. Longman,Inc Newyork.

[2]. Armstrong M. (2001). Human Resource Management Hand book ( $8^{\text {th }}$ edition) London: Kogan Page Limited.

[3]. Armstrong M. (2008). Human Resource Management Hand book ( $11^{\text {th }}$ edition) London: Kogan Page Limited.

[4]. Bratton, J. and J. Gold (2007). Human Resource Management: Theory and Practice.(4 ${ }^{\text {th }}$ ed.), Basingstoke: Palgrave Macmillan

[5]. Bunting, M. (2007) Training and Human Resource Development: A Critical Text, Basingstoke: Palgrave Macmillan

[6]. CIPD (2006a). Recruitment, Retention and Turnover Survey. www.cipd.co.uk.

[7]. CIPD (2006b). Overview of CIPD Surveys: a barometer of HR trends and prospects 2007. www.cipd.co.uk

[8]. Cole, G.A. (2002). Personnel and Human Resource management ( 5th edition) . Bookpower.

[9]. Crawford, R.B. (2004) "Recruitment and Selection," HR Research Paper No 30, 12 pages, HRDOC Store: London.

[10]. Dick, P. and A. D. Jankowicz (2006) Reproducing gender inequalities? A critique of realist assumptions' in journal of Occupational and Organizational Psychology 79,481 - 498

[11]. Ding, D., Goodall, K. and Warner, M. (2000) "The end of the 'iron rice-bowl': wither Chinese

[12]. human resource management?” International Journal of Human Resource Management, 11 (2), 217-236

[13]. Fishman, T.C. (2005). China Inc. How the rise of the next superpower challenges America in the World, New York: Scriber.

[14]. Goldrick, P. (1997) "What makes a selection system best practice?" HR Monthly, June, 26-27.

[15]. Huselid, M. (1995) "The impact of human resource management practices on turnover, productivity and corporate financial performance," Academy of Management Journal, 38 (3), 635-672.

[16]. Ichnioowski, C., Kochan, T., Levin, D., Olsen, C. and Strauss, G. (1996) .What works at work: Overview and assessment," Industrial Relations, 35 (3), 299-333.

[17]. Koontze, H. and Weighrich H. (1998). Essentials of management. New Delhi: Tata MCGraw Publishing Company.

[18]. MacDuffe, J. (1995) Human resource bundles and manufacturing performance organisational logic and flexible production systems in the world auto industry. Industrial and Labour Relations Review, 48 (2), 197-221.

[19]. Mondy, R.W. and Noe, R.M. (1993) Human Resource Management, New York: Allyn \& Bacon.

[20]. Nankervis, A., Compton, R. and Baird, M. (2002). Strategic Human Resource Management, Sydney: Thompson.

[21]. Ng, S.W. and R.J. Burke (2005). Person-organisation fit and the war for talent: does diversity management make a difference?' in International Journal of Human Resource Management 16, no. 7, 1195 - 1210

[22]. Oso, Y.W \& Onen, D. (2005). A General Guide to writing Research Proposals and Report. Kenyan Option Printers and Publishers.

[23]. Overman, S. (2001). Recruitment in China. HRMagazine, 46, p.86 [Retrieved $23^{\text {rd }}$ March, 2009 from ABI-INFORM database]

[24]. Patterson, M., West, M. Hawthorn, R. and Nickell, S. (1998) Impact of people management practices on business performance, Issues in People Management, No 22, Institute of Personnel and Development: Wimbledon.

[25]. Pilbeam, S. and M. Corbridge (2006). People Resourcing. Contemporary HRM in Practice, London: Prentice Hall Purcell, J., Kinnie,N., Hutchinson, S., Rayton, S. and Swart, J. (2003). Understanding the People and Performance Link: Unlocking the Black Box. CIPD.

[26]. Redman, T. and Wilkinson, A. (2006). Contemporary Human Resource Management: Text and Cases, New Jersey and Harlow: Pearson Education.

[27]. Republic of Kenya, (1963). The Local Government Act Cap 265. Government Printers. Nairobi

[28]. Searle, R.H. (2006). New technology: the potential impact of surveillance techniques in recruitment practices. Personnel Review 35, no. $3,336-35$

[29]. World Bank (2002). Financial Access: Measuring Access to Financial Services around the World. Washington DC 